\title{
The Predicate in English and Albanian Grammar Books
}

\author{
Dr. Suzana Samarxhiu \\ Lecturer at Aleksander Moisiu University, Durres, Albania, Faculty of Education, Department of Foreign Languages \\ Email:smrxh@yahoo.com
}

\section{Doi:10.5901/ajis.2015.v4n3s1p637}

\section{Abstract}

In almost all traditional and modern grammar books, it is admitted that simple sentence has two obligatory elements, its subject and predicate, which are named in different terms. On most occasions it is observed that the notion of the subject and predicate is known with other terms as topic- focus by Hokiti or theme-rheme by representatives of School of Pague. Representatives of Functional grammar are based on this approach as well. Certainly, these terms do not match with subject and predicate as a syntactic category of the language. Definitions of the subject and predicate often encounter problems, because the sentence contains not only obligatory elements it contains other optional elements as well.

\section{Introduction}

In almost all traditional and modern grammar books, it is admitted that simple sentence has two obligatory elements, its subject and predicate, which are named in different terms. On most occasions it is observed that the notion of the subject and predicate is known with other terms as topic- focus or theme-rheme by representatives of School of Pague. Representatives of Functional grammar are based on this approach as well. Certainly, these terms do not match with subject and predicate as a syntactic category of the language. Definitions of the subject and predicate often encounter problems, because the sentence contains not only obligatory elements it contains other optional elements as well.

Other difficulties arise, especially when it comes to the constituent elements of the predicate. Only be taken as predicate the verb or the verb with its obligatory element after it? According to us, it is a difficult issue, the solution of which is done in different ways by different linguists, starting from Sapir (1921), who said that there should be something to tell and something to say about the subject of discussion. According to him, the subject of discussion is a name, individual or thing around which something is said and predicated, statement made about the individual or the thing.

\section{Discussion}

We think that in the early Albanian and English grammar books, definitions of predicate suffer from a lack of a basic criterion, syntactic criteria. Grammarians' similar definitions appear as incomplete. Zanvoort (1966:196) says that the predicate is what is said to the person or thing that is marked by the subject.

Curme(1931:142) and Pawley (1030) point out that the predicate is the element that shows something about the subject. Briant and Jespersen (1933) say that the entire sentence, except the subject and its complements, is the predicate. Woods states that the predicate, which expresses an action, is that part of the sentence that states something about the subject.

A similar definition is given even by Woods (2001: 80) but O'Dwyer (2006:155) is more precised in his definition. According to him, "The predicate indicates a state or action which is at the beginning or at the end". In order to express its grammatical meanings, the predicate uses its transitional forms, intransitive verb or linking verb. The predicate in traditional grammar, which is accepted only in close connection with the subject grammatically and semantically, differs from the predicate of Generative grammar, whose predicate along with its arguments form the statement.

Statement is that aspect of the meaning of the sentence which relates to the authenticity or falsehood of meaning expressed by a certain sentence, so it expresses the semantics of the sentence. But it should be noted that the predicate does not express authenticity or falsehood features of perception of reality by the speakers, on the contrary, the statements of assertion do so. This gap created between the predicate and statement is supplemented by logical element, which enables connection of predicate to attitude towards reality.

On the other hand, Lyons $(1966,1977)$ narrows the concept of predicate in sentences, based o the triple division: subject, predicate and adverb. It therefore rejects all those linguists who claim that the verb refers to the whole sentence, 
except the subject. Radford (2009:9) analyzes predicate from a semantic point of view. "The subject and complements, he says, are the same, since both of them are involved in actions or events expressed through the predicate".

Representatives of Generative grammar unanimously say that the main function of predicate is to affirm something about the subject. According to them, the subject is the element that refers to the entity, which a statement or assertion is made, for the rest of the sentence. (Chomsky 1981)

Huddlestone (2002:182) claims that in sentence Ed loves Kim the semantic and syntactic criteria is melted in the predicate, which means "love" is used to formalize the relationship between Ed and Kim or together with the name Kim "love Kim" to state something about subject "Ed". According to him, the term predicate is used in syntax to name the element that enters into relationship with the subject.

Predicate is one of the main objects of study in the field of functional grammar (Webster 2013:130). The predicate brings something new in a sentence and its function is a verb that reflects the organizational structure of the sentence. Verb plays a central role in the scheme of connecting elements in a sentence, as well as in the structuring of the latter. On its right side, the verb requires the subject, and on the left it requires some complements.

Early Albanian grammarians, virtually as a predicate accept only the verb but when define and discuss about it, they claim that the predicate is "what is said for the subject". In these linguists (Ahmataj 1997), we notice see a contradictory position between the definition and the practical division of the predicate elements made in grammar books. So, our linguists consider as a predicate only the verb.

Xhuvani (1922) says "Predicate is a verb only when the predicate itself is manifested by a verb". Meanwhile Sheperi(1927:141) defines the predicate as "simple verb ". For Justin Rrota (1942:456) the predicate is formed by a verb which indicates something about the subject. Among all the linguists of that time, Cipo (1952:62) gives a more detailed definition about the predicate such as "Predicate is called the verb when it itself fulfills the meaning". Definitions of early grammar books differ from the latest ones. Nowadays linguists consider a verbal element semantically only when it enters into predicative relationship with the subject and if no subject exists in the clause, no predicate exists, as a result the verb in this case is the main element in the clause.

Prifti (1971:60) defines the predicate as the word that shows what is claimed or denied to the subject. According to him, the predicate is the main part of the sentence and without it the subject cannot be formed, but grammatically it is closely related to the subject. On the other hand Dhima (2010:75-76) claims that the predicate is the main element of the clause expressed by a verb which enters into predicative relation with the subject. Çeliku (2012:145) emphasizes that the predicate, as the subject is the main element of the sentence that shows action, condition or quality of the person or the thing expressed by the subject.

The structure of predicate can be a finite verb form or a verbal expression that indicates mood, tense, aspect, number, etc. But it may also have other components that precede each other and have no semantic dependence. In syntactic analysis such constructions are treated as a single element of the sentence, known as compound predicate. Grammarians argue that, based on this view, the compound predicate forms a unique communicative content. Based on its components, the compound predicate is classified into: a) verbal compound predicate, denoting the start, continuation or termination of an action or modality; b) nominal compound predicate formed by the copula and the nominal part that might be a noun, an adjective, a noun phrase, adverb and pronoun.

Many grammar books accept that the nominal predicate is characterized by the linking hypothesis. This hypothesis implies a close connection of the copula and the element after it in order to express grammatical and lexical meanings. In the sentence "John is clever" the nominal predicate is "is clever" and shows a feature of the subject, so John has the feature of being "clever". Such a sentence structure demonstrates the close relationship between the semantic and syntactic interface. Analyzing this sentence, we say that of course it is informative, to the extent that we know what "features" are which are the actions that we can perform (for example, on what conditions we can unite two properties or qualities of the an entity). The exact syntactic and semantic connection is [subject + feature]. Copula part of the nominal predicate cannot be studied apart from its nominal part.

\section{Conclusion}

Concluding this study, we say that the problematic issues that were observed in relation to the predicate have to do the definitions which sometimes appear to be incomplete. For traditionalists, the predicate is accepted only in close connection with the subject and expresses mood, tense. This approach differs from generativist representatives. We support generative approaches which state that the verb with its arguments form the predicate. But at the same time, we think that they are somewhat contradictory to claim that semantic and syntactic interfaces of predicate are not studied 
separately each other, while the syntactic interface of the predicate is studied within the scope of the theory X-bar, whereas semantic interface is studied within theta theory.

Important for us are functionalist views as well whose predicate reflects the organizational structure of the sentence.

As a conclusion, we strongly believe that the predicate is a very essential element of the clause which serves to describe an action or condition of the subject. In many cases, the predicate cannot describe the subject alone, so it is important that it be followed by other elements which are essential in the sentence.

\section{References}

Ahmetaj. B. Studime. Filologjike, Nr. 4. Universiteti i Prishtinës, 1997, pg 202.

Bryant, M. A functional English grammar,D.C. Heath and Company. 1945, pg 326.

Çeliku, M. Sintaksa e gjuhës shqipe, Vështrim i ri teorik, lliar, Tiranë, 2012, pg 145.

Chomsky, N. Aspects of the Theory of Syntax. Cambridge: The MIT Press.1965, pg 128.

Chomsky, N.( 1981), Lectures on Government and Binding: The Pisa Lectures. Holland: Foris

Publications.Reprint. 7th Edition. Berlin and New York: Mouton de Gruyter, 1993.

Cipo, K. Sintaksa , Instituti i Shkencave, Tiranë, 1952, pg 62.

Danes, PG One instance of Prague School Methodology: Functional Analysis of Utterance and Text. 1970. In Garvin P.L. (ed), Method and Theory in Linguistics, pg 130-140, The Hague: Mouton.

Dhima, Th. Gjuha Shqipe, Sintaksa, Gjirokastër, 2010, pg 75-76.

Domi, M. Gramatika e gjuhës Shqipe II, Sintaksa, Tiranë, 1954, pg 36.

George, O. Curme. The grammar of English language,Vol. III, Syntax, Boston, 1931, pg 142.

George, R. Carpenter, English grammar, New York, The Macmillan Co.1907, pg 5.

Halliday M.A.K., Halliday in the 21st Century, Volume 11, Jonathan Webster, 2013, pg 130.

Huddelston, R. and Pullum, G; Introduction to English language, Cambridge University Press, 2002, pg 182.

Jespersen, O. (1933), The Essential of english grammar. First published by Routledge, an imprint of Taylor \& Francis Group, 2007, pg 97-98.

Lyons, J. Introduction to Theoritical Linguistics, Cambridge University Press, 2ed. 1969.

Lyons, J. Semantics. Vol II. Cambridge university Press, 1977.

O'Dwyer, B. Modern English Structures, second edition: Form, Function, and Position, Broadview Press, 2 ed. 2006, pg155.

Prifti, S. Sintaksa e gjuhës shqipe, Universiteti i Prishtinës, 1971 pg 60. (Botim i dispensës së Universitetit të Tiranës, Fakulteti i Histori Filologjisë, Tiranë 1962)

R. W. Zandvoort. A handbook of English grammar (Englewood Cliffs, N. J, 1966) pg 196.

Radford. A. Analysing English Sentences: A Minimalist Approach, 2009, pg 9.

Rrota, J. A. Syntaksa e Gjuhës Shqipe për klasën e II, III, IV të shkollave të mesme, Shkodër, Shpija Botuese , A.Gj. Fishta. 1942, pg 456.

Sapir, E. An introduction to the study of speech, New York, Harcourt, Brace.1921.

Sheperi.I.D. Gramatika dhe Syndaksa e gjuhës shqipe, Vlorë, 1927, pg 141.

Stalmaszczyk, Piotr. On defining predication in generative grammar, Papers and studies in contrastive linguistics, Vol.34, 1998, pg 101121.

Thomas. D. Pawley, A modern advance English grammar for secondary schools and colleges, Baltimore, 1930, pg 1.

Totoni, M. Libri i gjuhës shqipe për klasën VII. Tiranë, 1971. Gramatika e gjuhës shqipe II, Tiranë, 1996, pg 173.

Woods, G. English for dummies, The New Yorker, Vol. 56. 2001, pg 80.

Xhuvani, A. Njohunitë e para të syntaksës shqipe, Pjes' e parë, 1922, pg 9.

Xhuvani, A. Sintaksa Shqip, Njohnit e para të sintaksës shqipe, Shttypshkronja Teknike, Tiranë, 1933, pg 8. 